\title{
【年頭 所感】
}

\section{夢のある循環型経済社会への変革}

\author{
廃棄物学会会長 由 勝
}

新年明けましておめでとうございます。

昨年は，米国の同時多発テロ事件，炭疽菌事件，狂牛病騒ぎ等，暗い ニュースが多かったわけですが，年末には皇太子ご夫妻にお子様の誕生 と明るいニュースが飛び込んできました。今年も明るい話題で夢のある 年にしたいものです。

廃棄物の世界では，家電りサイクル法が施行され，自治体の処理から 生産者の責任で回収, リサイクルへと大きく方向転換されることになり ました。またPCB 処理促進法の法整備がされ，20 世紀に残された最大

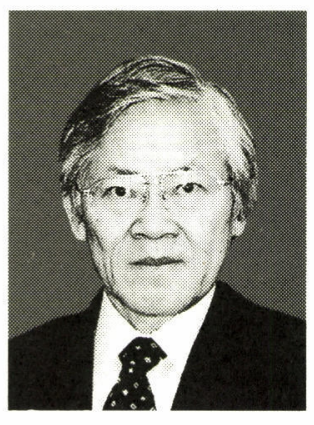
の産業廃棄物問題, PCB の処理が今年から一気に促進されることと思います。このように資 源の保全や環境負荷の低減のためにシンボル的に二つの法律が施行されました。

私たちの廃棄物学会は, 設立 12 年目を迎え, 個人会員, 公益会員, 賛助会員を加えて 4,000 名を超える団体になり, 今でも会員は増えつづけています。学会の会員が増えているこ とは, 廃东物問題が山積している今日, 廃棄物学会への期待がますます大きくなってきてい るからと思われます。

廃衰物が適正に処理されるために, 解決しなければならない問題がたくさんあります. 学 会の皆さんの調查や研究の成果が，このような問題の解決のために生かされ，科学的なデー 夕や知見に基づいて，合理的に解決されればと願っています。施策の効果を定期的に見直し， 科学的根拠に基づく廃棄物行政を推進し, また現場での適正な廃棄物処理の推進に, 廃棄物 学会は技術面や科学面でサポートすることが望まれています。

今年度む, 今までに行ってきた学会誌（和文, 英文) や学会ニュースレター（和文, 英文) の発行, 研究発表会やセミナーの開催, 研究の活性化のための助成など, 色々な事業を実施 してまいりました。また, そのような背景の下, PCB 廃革物や, 感染性廃棄物, ダイオキシ ン污染廃棄物の処理など有害廃棄物問題を議論すべく, 廃裹物学会が中心になって，環太平 洋有害廃棄物国際会議を成功裏に岡山で開催することが出来ました。ご支援いただいた皆様 にこの場を借りて，厚くお礼を申し上げます。

私達が, 健康で快適かつ便利で豊かな生活を追い求めた結果として, 20 世紀は大量生産, 大量消費，大量廃棄の社会になったといわ饥ています。日常生活，事業活動に伴って生じる ごみの量は, 日本全体では 1 年間に 5,000 万 ton にもなり,この他にも年間 4 億 ton の産業 廃衰物が排出されています。 
経済水準の向上や，消費者に便利な使い捨て型の商品の増加は，消費量の増大，廃棄物発 生量の増大をむたらしました。廃棄物は資源消費のバロメータと見ることが出来ます。した がって 21 世紀には地球サミットでも決めた私たちの目指すべき社会, 資源の消費を㧕制し, 廃衰物の排出を最小化し，環境負荷の少ない循環型社会を作ろうと目指しています。

このような目標の下に，私たちの意識の変革が求められ，生産者から消費者まで関係者の 努力によって，廃棄物の発生抑制，リサイクルの増大を図ってきました。それぞれの都市で は，スリム作戦や，ダイエット作戦といった施策を展開しています。

そのような努力の効果ああって，廃累物量の増大は止まりましたが，同時に経済の減速を 経験しています。そこで何かと経済の回復のために，生産や売り上げの増大を目指した施策 が展開されておりますが，これは資源消費の増大や廃棄物発生の増大に繫がるのではないか と危惧しています。経済の回復と循環型社会の形成についてどのように整合性を図るかがま すます重要になってきました。

社会の豊かさや素晴らしさを, 従来のように GNP のみで計るのではなく，循環型社会指 標という新しい指標でもって計り，それを競い合うことが重要ではないでしょうか。日本の 社会む， 20 世紀の物差しである GNP では，世界のトップクラスになりました。循環型社会 指標であ世界のトップクラスになるためには，最適消費，それに見合った最適生産，その結 果排出される“ほどほど廃棄”に努め，その努力や効果に対する評価を通じて国民が誇りを 持つとともに元気の続く社会にしたいものです。

私あ内閣府の経済財政諮問会議専門調查会メンバーとして, 循環型経済社会の実現に向け た課題についてできるだけ俯瞰的視点から検討を行いました。調査会では，国民が共有すべ き基本的なビジョンとその実現に向けたシナリオを明確化することを目的に，昨年 11 月末に 「循環型経済社会に関する専門調查会」中間取りまとめを発表しました。その内容として, 1）ごみを「不要なもの」から「資源・エネルギー」として活用する社会へ転換，2）2050 年までに埋め立て処分量を 10 分の 1 にすること， 3 ）情報へッドクォーターの創設を柱にし て提言しています。その詳細に関しては，インターネット（経済財政諮問会議ホームページ） を見ていただきたいと思います。

私達は，思い描く理想像と現実とのギャップを問題として捉えます。廃棄物処理において もこうした理想像を目指して多くの努力がなされてきました。しかし，いっまでたってもそ のような理想にはなかなか到達できず，むしろ，理想像と現実とのギャップがどんどんと広 がるなど，廃棄物問題はますます深刻化してきております。

廃棄物処理の理想像として, 従来は公衆衛生・生活環境保全の高いレベルを思い描いてき ました。そしてその理想を実現するための努力を進めてきました。その結果として，生活の 場から廃棄物は速や加排除され，衛生状態は極めてよくなりました。しかし，処理に伴う 環境リスクは極端に小さくなってきたにもかかわらず，理想とはほど遠いと思われているの が現状です。

最近では，循環型社会形成に向けて資源の保全が期待され，全国各地において容器包装や 廃家電などのリサイクルに向けての取組みが進むようになりました。しかし,ペットボトル 
や生ごみなどの回収をもっと進めてリサイクル率を高めることが時として要求されます。

こうした処理の高度化, リサイクルの拡大が進む中で, その好理コストあ急速に増加して おります。環境保全・リサイクルが声高に叫ばれる中, 清掃事業自体の効率の向上も求めら れるようになってきました。

これまでの現実を理想に近づける努力を重ねて今の現実が成り立っております。行き着く ところまでいくと，これ以上努力をしてあその効果は見えにくくなってきました。財政上も 限りがあり，住民の分別にも限界があります。思い描かれる理想が，現実の制約を忘れた， 実行不可能なものとなってしまい，それが処理施設や最終処分場の整備を困難にしているの ではないでしょうか。

与えられた制約条件の中で実行可能な施策としては，現実の廃棄物処理がザ・ベストであ ることを関係者への説明を通じて理解してあらう必要があると考えております。このような 努力あ廃棄物問題を解決するための重要な方策ではないでしょか。

廃棄物学会に目を向けると, 学会運営においては, 学会のホームページを充実する等まだ 残された課題もたくさんあります。賛助会員の増加を通じて学会の財政体質を好転させ，サ ステーナブルな学会にしなければなりません。また学会として，なんであかんであやるので はなく，やるべきことに優先順位をつけてメリハリをつけ，効率よく活動していきたいと考 えています。そのような意味で，会員の間であ議論していただき，改革をすべき所は改革を 断行していきたいと思います。法人化についても，そのめどは立っておらず，未だ不透明の ままです。今まで文部科学省に対して色々資料を準備して対応を重ねてきましたが，いつ法 人化されるのかわからないという状況です。

このように期待されている学会は，運営するのも学会員，負担するのも便益を受けるのも 学会員であります。会員中心の，そして，開かれた夢のある学会を目指して改革を進めてい きたいと思います。どうぞ廃棄物学会をこれまで以上にご支援くださいますようよろしくお 願い申し上げます。

皆様のご健勝を祈念して，新年のご挨拶とさせていただきます。

(岡山大学大学院自然科学研究科教授) 